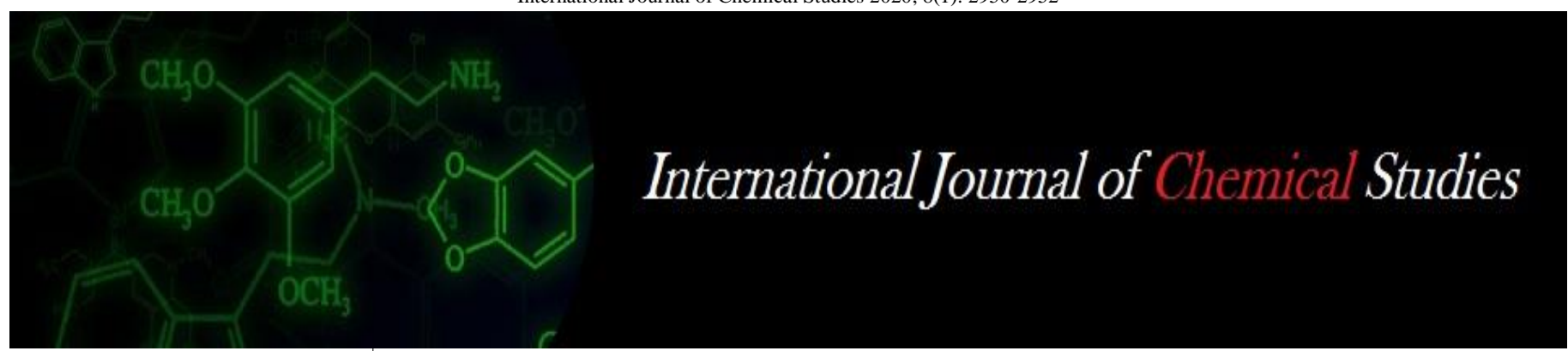

P-ISSN: 2349-8528

E-ISSN: 2321-4902

www.chemijournal.com

IJCS 2020; 8(1): 2950-2952

(C) 2020 IJCS

Received: 09-11-2019

Accepted: 13-12-2019

Pradeep Kumar Bairwa

Department of Horticulture,

Babasaheb Bhimrao Ambedkar

University (A Central

University) Vidya -Vihar, Rae

Bareli Road, Lucknow, Uttar

Pradesh, India

\section{RS Verma}

Assistant Professor, Department of Horticulture, Babasaheb

Bhimrao Ambedkar University (A Central University), Vidya

Vihar, Rae Bareli Road,

Lucknow, Uttar Pradesh, India

\section{Harvindra Pal}

Department of Horticulture, Babasaheb Bhimrao Ambedkar University (A Central

University) Vidya-Vihar, Rae Bareli Road, Lucknow, Uttar

Pradesh, India

Som Prakash

Department of Horticulture, Babasaheb Bhimrao Ambedkar University (A Central

University) Vidya -Vihar, Rae Bareli Road, Lucknow, Uttar

Pradesh, India

Shivendra Kumar

Department of Horticulture, Babasaheb Bhimrao Ambedkar University (A Central

University) Vidya -Vihar, Rae Bareli Road, Lucknow, Uttar Pradesh, India
Corresponding Author: RS Verma

Assistant Professor, Department of Horticulture, Babasaheb

Bhimrao Ambedkar University (A Central University), Vidya Vihar, Rae Bareli Road, Lucknow, Uttar Pradesh, India

\section{Studies on chemical characters of different cultivars of aonla (Emblica officinalis Gaertn.) in awadh region}

\author{
Pradeep Kumar Bairwa, RS Verma, Harvindra Pal, Som Prakash and \\ Shivendra Kumar
}

DOI: https://doi.org/10.22271/chemi.2020.v8.i1as.8717

\begin{abstract}
A field experiment was conducted during 2018 at the collection of different varieties of aonla in N.D.U.A\&T Faizabad than carried out in the laboratory Department of Horticulture, Babasaheb Bhimrao Ambedkar University, Lucknow. Studies on chemical characters of different cultivars of Aonla (Emblica officinalis Gaertn.) in Awadh region revealed that the maximum Juice percent (38.70\%), T.S.S. (10.40 ${ }^{\circ}$ Brix), Acidity percent $(1.60 \%)$,Vitamin-C $(566.49 \mathrm{mg} / 100 \mathrm{~g})$, Total Sugar percent $(7.70 \%)$, Reducing sugar percent $(4.57 \%)$, Non- Reducing sugar percent $(3.51 \%)$. was recorded in cultivars (NA-7, NA-10, Francis, Laxmi-52, NA-7, Laxmi-52, Kanchan) respectively.
\end{abstract}

Keywords: Aonla, chemical parameters

\section{Introduction}

Aonla or Indian gooseberry (Einblica officinalis Gaertn.) belong to the family Euphorbiaceae with chromosome number of $2 n=28$. It is suitable for semi-arid region and withstands well in acidity and drought conditions, has found it suitable for various type of wasteland. It is hardy prolific bearer and highly remunerative even without much care and can be successfully grown in variable agro-climatic and soil conditions. The tree is much branched and ranges 8-18 $\mathrm{m}$ in height with thin light grey bark. Small thin irregular flakes leaves are simple, subsessile, closely set along the branchlets, colour light green and having the appearance of pinnate. Flowers are greenish yellow in axillary fascicles, unisexual, males numerous on short slender pedicels, females few, subsessible, ovary 3 celled; fruits globose, fleshy, pale yellow with six obscure vertical furrows enclosing six trigonous seeds in 2 seeded 3 crustaceous cocci. It is deciduous under north Indian conditions, however, it is considered as evergreen in the tropics. it can be successfully grown even in sodic and saline soils upto 35 ESP and 10Ece/ds respectively with maximum 9.5 soil $\mathrm{pH}$. Though aonla is a subtropical fruit but its cultivation in tropical climate is quite successfully. It responds well to the conditions of dry weather, moderately cool temperature during winter followed by high temperature of summer. It can tolerate freezing temperature as well as temperature as high as $46^{\circ} \mathrm{c}$. The fruits are highly nutritive and one richest sources of vitamin-C. Out of 100 gram edible portion of Aonla, it contain $0.5 \mathrm{gm}$ protein, $0.1 \mathrm{gm}$ fat, $0.7 \mathrm{gm}$ minerals, $1.9-3.4 \mathrm{~g}$ fibers, $14.1-21.8 \mathrm{gm}$ carbohydrates, $0.05 \mathrm{gm}$ calcium, $0.02 \mathrm{gm}$ phosphorus, $1.2 \mathrm{gm}$ iron and 200-750 mg vitamin-C Mehta et al. (2002) ${ }^{[4]}$. The fruits contain a chemical substance called 'leucoanthocyanins' which retards oxidation of vitamin-C. Aonla probably the only fruits to till the gap of astringent food recommended by the ayurvedic system of medicine for a balanced diet and sound health. It is acidic, cooling, refrigerant, diuretic and laxative. Aonla is the main ingredients in Chavanprash and Triphla used in the treatment of headache, constipation and enlarged lever. Aonla distributes to all parts of India. In India it occupies nearly 93.000 ha. of area with annual production of 1.75 lakh tones. U.P. ranks first in both area and Production. It covers about 15750 ha area under aonla cultivation and production. Productivity potential and quality of any fruit crop are governed by the cultivars, nutrients status of soil, and the performance of cultivars under the given situation. In aonla, even after it's hardy nature there 
are problems like shy nature of bearing and inferior quality of fruits in seedlings which may or may not have high yield potential as well as good nutritive value. However. most of existing commercial cultivars (Banarsi, Chakaiya, Fransis, Krishna and Kanchan), are the selections from the existing seedling population and there are scope in future for further selection of promising type from seedling population for one or more outstanding characteristics.

\section{Materials and Methods}

Ten varieties/genotypes of aonla were selected to see their chemical composition which are collected from Narendra Dev University of Agriculture and Technology Faizabad UP. Collection of fifty (50) healthy, uniform sized fruits free from diseases, pests and brushes randomly selected from the trees of each cultivars from each direction. when the fruits is nearly matured, then it was picked up and taken for experiment in the month of November. Details of varieties /genotype are as follows: Banarasi, Chakiya, Laxmi-52, Krishna, Francis, Anand-1, Kanchan, NA-6, NA-7, NA-10. Observations recorded to be Juice (\%), T.S.S. ( ${ }^{0}$ Brix), Acidity (\%), Vitamin C (mg/100g), Total Sugar (\%), Reducing sugar (\%), NonReducing sugar (\%). The data so obtained were analysed statistically. Analysis of different variable was carried out to know the degree of variation amongst all the treatments. The data were statistically analysed by the method given by Panse and Sukhatme (1963). The chemical analysis was carried out as per method given by AOAC (1980).

\section{Results and Discussion}

The percentage of juice in different varieties/genotype of aonla varied from $24.20 \%$ to $38.70 \%$. The highest juice percentage was observed in genotype NA-7 (38.70\%) and it was found minimum in variety Kanchan (24.20\%) This variation may be due to more moisture content in genotype JEO-1 and less moisture content in variety Kanchan. The increase in fruit juice and fruit weight was significant and rapid upto seventy-five days after fruit set and thereafter, a slow, but steady increased was observed upto 90 days after 90 days. There was no increase in fruit juice of aonla fruits. While total soluble solids was ranged from 3.50 Brix to 10.40
Brix and the maximum T.S.S. was noted in NA-10 followed by in variety Banarasi and the minimum was noted Variety NA-6. The variation in T.S.S. existing variability in varieties/genotypes, inheritance, micro-climates. cultural practices, photosynthetic efficiency, synthesis of metabolites and maturity indices of different varieties/genotypes of aonla. These findings are well in agreement with the results of Balasubramanyam and Bangaruswamy (1998) ${ }^{[2]}$ who studied the maturity standard of aonla and reported low T.S.S. in the immature fruits and a steady increase in T.S.S. content was observed 120 days after fruit set $\left(10.2^{\circ}\right.$ Brix). This might be due to conversion of starch into sugar as maturity advanced. Vitamin- $\mathrm{C}$ and acidity is an integral part of an Ayurvedic formulation. The results show very little differences in the acidity but a distinct and wide variation of ascorbic acid was recorded among the various varieties/genotypes. The maximum ascorbic acid was recorded in genotype NA-6 $(583.13 \mathrm{mg} / 100 \mathrm{~g})$. Whereas, minimum $(419.19 \mathrm{mg} / 100 \mathrm{~g})$ ascorbic acid content was found in variety Banarasi. The acidity of different varieties/genotypes varied from $0.95 \%$ (Banarasi) to $1.60 \%$ (francis). The variation in ascorbic acid and acidity content of different genotypes of aonla may be due to genetical characteristics of genotypes, micro-climates cultural practices and maturity indices of the fruits. Variation in ascorbic acid and acidity content of different varieties / genotypes of aonla was also reported y Mehta et al. (2002). They reported maximum ascorbic acid and acidity in local seedlings followed by in Banarasi which was significantly higher than rest of the cultivars. Total sugar was observed in different genotype of aonla there total sugar are varied ranges from $7.36 \%$ to $7.70 \%$. the maximum total sugar was variety of NA-7 $(7.70 \%)$ followed the variety of NA-10 and the minimum total sugar was variety of Laxmi-52 (7.36\%). Reducing sugar was analysed varieties and genotype of aonla fruits the reducing sugars are analysed varied from $3.97 \%$ to $4.57 \%$ the maximum reducing sugar was varieties of Laxmi$52(4.57 \%)$ and the minimum reducing sugar was varieties of francis(3.97\%).in case of Non reducing sugar seen the highest non reducing sugar variety of $(3.51 \%)$ followed the francis $(3.45 \%)$, whereas lowest is laxmi-52 $(3.00 \%)$.

Table 1: Effect of chemical characters of different cultivars of Aonla (Emblica officinalis Gaertn.) in Awadh region

\begin{tabular}{|c|c|c|c|c|c|c|c|}
\hline $\begin{array}{l}\text { Varieties/ } \\
\text { genotypes }\end{array}$ & $\begin{array}{l}\text { Juice } \\
(\%)\end{array}$ & $\begin{array}{l}\text { T.S.S. } \\
\left({ }^{0} \text { Brix) }\right.\end{array}$ & $\begin{array}{c}\text { Acidity } \\
(\%)\end{array}$ & $\begin{array}{l}\text { Vitamin C } \\
(\mathrm{mg} / 100 \mathrm{~g})\end{array}$ & $\begin{array}{c}\text { Total Sugar } \\
(\%)\end{array}$ & $\begin{array}{c}\text { Reducing sugar } \\
(\%)\end{array}$ & $\begin{array}{c}\text { Non- reducing sugar } \\
(\%)\end{array}$ \\
\hline Banarasi & 30.50 & 10.06 & 0.95 & 531.86 & 7.49 & 4.33 & 3.16 \\
\hline Chakaiya & 34.46 & 7.26 & 1.26 & 524.10 & 7.48 & 4.12 & 3.31 \\
\hline Laxmi-52 & 32.63 & 8.76 & 1.56 & 566.49 & 7.36 & 4.57 & 3.00 \\
\hline Krishna & 33.56 & 9.10 & 1.39 & 548.65 & 7.50 & 4.34 & 3.16 \\
\hline Francis & 38.10 & 9.13 & 1.60 & 560.97 & 7.42 & 3.97 & 3.45 \\
\hline Anand-1 & 33.15 & 9.60 & 1.26 & 540.60 & 7.52 & 4.13 & 3.35 \\
\hline Kanchan & 24.20 & 7.10 & 1.59 & 419.19 & 7.48 & 3.97 & 3.51 \\
\hline NA-6 & 31.20 & 3.50 & 1.30 & 583.11 & 7.38 & 4.36 & 3.02 \\
\hline NA-7 & 38.70 & 7.06 & 0.95 & 426.11 & 7.70 & 4.53 & 3.17 \\
\hline NA-10 & 36.09 & 10.40 & 1.26 & 532.82 & 7.53 & 4.26 & 3.27 \\
\hline C.D. at $5 \%$ & 1.36 & 0.73 & 0.31 & 21.76 & 0.12 & 0.13 & 0.08 \\
\hline SEm \pm & 0.46 & 0.24 & 0.10 & 7.32 & 0.04 & 0.04 & 0.04 \\
\hline
\end{tabular}

\section{References}

1. AOAC. Official Method of Analysis, Association of Official Agricultural Chemists, Washington D.C. USA, 1980.

2. Balasubramanyam S, Bangaruswamy. Studies on maturity standard of aonla (Emblica officinalis Gaertn.) under rainfed vertisol soil. South Indian 1-fort.Sci. 1998; 46(5\&6):347-348.
3. Kumar S, Baig MJ, Singh RC, Kumar S. comparative study of aonla cultivars in relation to physico- chemical properties. Range managements \&Agro forestry, Indian grassland and fodder research institute, Jhansi. 2001; 22(1)128-129.

4. Mehta S, Godara RK, Bhatia SK, Kumar S. Studies on physico-chemical characteristics of various cultivars of 
aonla (Emblica officinalis Gaertn.) under semi-arid conditions. Haryana J Hort, Sci. 2002; 31(1\&2):17-19.

5. Panse VG, Sukhatme PV. Statistical Methods for Agricultural Workers, ICAR Publication, New Delhi, 1984, 359.

6. Singh JN, Singh SP, Lai Bahadur Determination of maturity standard of aonla (Emblica officinalis Gaertn.) cultivars under eastern conditions of U.P. Haryana J Hort. Sci. 1989; 4:216-220. 